\title{
OCCUPATIONAL ALLERGY TO LIMONIUM SINUATUM — A CASE REPORT
}

\section{MARTA WISZNIEWSKA, CEZARY PAŁCZYŃSKI, PATRYCJA KRAWCZYK-SZULC, TOMASZ WITTCZAK, ALEKSANDRA CYRAN, and JOLANTA WALUSIAK-SKORUPA}

Nofer Institute of Occupational Medicine, Łódź, Poland

Department of Occupational Diseases and Toxicology

\begin{abstract}
Decorative flowers are known to be a cause of occupational allergy in the floral industry. The allergic manifestations induced by flowers include asthma, rhinoconjunctivitis and urticaria. We present a case of a 55-year-old woman, who has been working for the last 30 years as a gardener with various kinds of flowers, e.g., Limonium sinuatum (LS), chrysanthemum, sweet William (Dianthus barbatus) and Lilium. During the last 10 years she has developed nasal and eyes symptoms, dry cough, dyspnoea, chest tightness and wheezing. Clinical examination, routine laboratory testing, chest radiography, skin prick tests (SPT) involving common allergens, native plants pollens and leaves by the prick-prick technique, rest spirometry, methacholine challenge test and specific inhalation challenge test (SICT) were conducted. SPT results to common allergens were positive for grass pollens. SPT with native plants pollens and leaves showed a positive reaction only for LS. SICT induced an isolated early asthmatic reaction and significant increase in the number of eosinophils in the nasal lavage fluid. Additionally, significant increase in non-specific bronchial hyperreactivity was observed after SICT. To our knowledge, the presently described report is the first one of Limonium sinuatum induced occupational asthma and rhinitis in a Polish gardener.
\end{abstract}

Key words:

Limonium sinuatum, Occupational asthma, Rhinitis

\section{INTRODUCTION}

Although decorative flowers are known to cause occupational allergy in the floral industry, case reports of occupational allergy to flowers can hardly be found in the literature. The allergic manifestations induced by flowers include asthma, rhinoconjunctivitis and urticaria. Jong et al. selected thirteen different flowers causing type I allergy [1]. Limonium sinuatum (LS), commonly known as wavyleaf sea-lavender, belongs to the Plumbaginaceae family, and it is commonly grown in the Mediterranean regions (Photo 1). Ueda et al. reported three cases of occupational allergy to LS among statis growers [2]. There

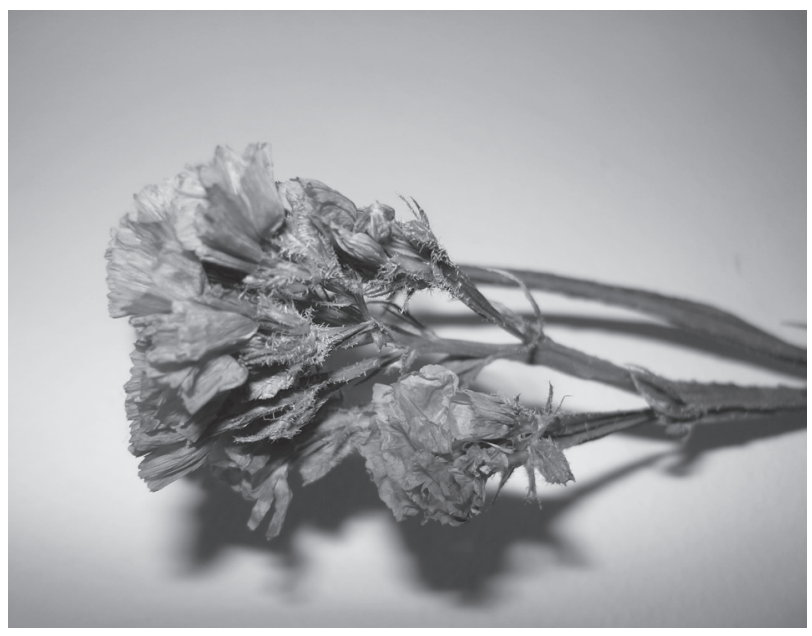

Photo 1. Dried Limonium sinuatum flowers.

Received: February 2, 2011. Accepted: April 7, 2011.

Address reprint request to M. Wiszniewska, Department of Occupational Diseases and Toxicology, Nofer Institute of Occupational Medicine, św. Teresy 8, 91-348 Łódź, Poland (e-mail: martaz@imp.lodz.pl). 
has been one case report of occupational asthma and contact urticaria induced by Limonium tataricum in a flower supplier [3]. Our report presents the first case of occupational asthma and rhinitis to Limonium sinuatum in a Polish gardener.

\section{CASE REPORT}

A 55-year-old, non-smoking woman was admitted to the Department of Occupational Diseases with suspected occupational asthma and rhinitis. She has been working for 30 years as a gardener with various kinds of flowers, e.g., Limonium sinuatum, chrysanthemum, sweet William (Dianthus barbatus) and Lilium. Throughout 10 years she has developed nasal and eyes symptoms, dry cough, dyspnoea, chest tightness and wheezing. The symptoms occurred from spring to autumn, mainly during work with LS, chrysanthemum, sweet William and lily. The patient noticed that the symptoms improved during the weekend and over vacations. Asthma has been recognised and, for 5 years, the patient has been treated with inhaled steroids and salbutamol, which resulted in partial improvement. She had no family or personal history of atopy. The patient works with flowers all the time. She also worked with them before the examination at the department.

\section{METHODS}

Clinical examination, routine laboratory testing, chest radiography, skin prick tests (SPT) with common allergens including tree and grass pollens, Dermatophagoides pteronyssinus, Dermatophagoides farinae, Acarus siro, Thyrophagus putrescentiae, Lepidoglyphus destructor, feathers and molds (Allergopharma, Germany) were performed. Also SPT with native plants pollens and leaves (LS, white and yellow chrysanthemum, lily) by the prick-prick technique, as well as rest spirometry and methacholine challenge test (Mijnhardt spirometer, the Netherlands) were conducted. After that, specific bronchial challenge test (SICT) involving simulation of workplace conditions with Limonium sinuatum, aster, lily and chrysanthemum was performed.

\section{RESULTS}

Physical examination showed no abnormalities and chest radiography was within normal limits. Chronic simple pharyngitis and laryngitis were recognized by othorinolaryngology specialist. The baseline spirometric values were as follows: $\mathrm{FVC}=2.841$ (109\%), $\mathrm{FEV}_{1}=2.331(106 \%)$, $\mathrm{FEV}_{1} / \mathrm{FVC}=82 \%, \mathrm{MEF}_{50}=2.14 \mathrm{l} / \mathrm{s}(59.3 \%)$. Laboratory tests were normal, except the elevated eosinophil count $(13 \%)$. Skin prick tests with common allergens were positive for grass pollens. SPT with native plants pollens and leaves showed a positive reaction only for LS $(3 \times 14 \mathrm{~mm}$ wheal and erythema response while the histamine reaction was $5 \times 25 \mathrm{~mm}$ ). Tests with the same extracts were performed in two control subjects with negative results.

Specific bronchial challenge test induced an isolated early asthmatic reaction and a significant increase in the number of eosinophils in the nasal lavage fluid (Table 1). Additionally, significant increase in non-specific bronchial hyperreactivity was observed after SICT $\left(\mathrm{PC}_{20}=1.33 \mathrm{mg} / \mathrm{ml}\right.$ before and $\mathrm{PC}_{20}=0.32 \mathrm{mg} / \mathrm{ml}$ after SICT).

Table 1. The cytological changes in the nasal lavage fluid (NLF) during a specific challenge with flowers

\begin{tabular}{lccc}
\hline \multirow{2}{*}{ Type of cells } & \multicolumn{3}{c}{ Cell count in NLF (\%) } \\
\cline { 2 - 4 } & $\begin{array}{c}\text { before } \\
\text { challenge }\end{array}$ & after 4 hours & after 24 hours \\
\hline Epithelial & 25 & 28 & 29 \\
Neutrophil & 73 & 66 & 65 \\
Eosinophil & 2 & 6 & 6 \\
Basophil & 0 & 0 & 0 \\
Lymphocyte & 0 & 0 & 0 \\
Monocyte & 0 & 0 & 0 \\
\hline
\end{tabular}




\section{DISCUSSION}

Limonium sinuatum belongs to ornamental dried flowers. It is commonly used in floral arrangements as it is a longlasting plant. Occupational asthma (OA) due to decorative flowers has been rarely described, mainly in case reports. To our knowledge, the presently described report is the first case of Limonium sinuatum induced occupational asthma and rhinitis in a Polish gardener.

In the present paper, the clinical history suggested occupational airway allergy. On the other hand, some epidemiologic surveys suggest that questionnaires are sensitive but not specific for identifying OA [4]. The incorrect diagnosis was found in $26 \%$ of suspected cases of sensitizer-induced OA from history alone compared with SICT [5]. Therefore, the importance of the further assessment among patients with a positive history of OA was emphasized [6].

As the diagnosis of occupational asthma and rhinitis needs to be confirmed by means of objective methods, the assessment of sensitization was performed. Our patient in a prick-prick test had a clearly positive reaction to Limonium sinuatum and this plant was related to her symptoms in the workplace. Even though SPT with common allergens were positive for grass pollens, the occupational origin of reported symptoms was confirmed. The diagnostic process of flower allergy is difficult in some cases, as standardized allergens extracts for skin prick or blood tests for specific IgE are unavailable. The sensitivity and specificity of prick-prick tests from flowers are unknown. On the other hand, in most cases of occupational allergy caused by ornamental flowers, unstandardized extracts for SPT or prick-prick tests were used to demonstrate specific sensitization [1,7-10]. The use of native plants pollens and leaves extracts for prick-prick tests has been recommended for screening flower allergy [1].

In our patient, the diagnosis of type I hypersensitivity was strongly suggested by the positivity of SPT, while the significant changes in SICT supported the recognition of occupational asthma and rhinitis. Specific bronchial challenge test induced an isolated early asthmatic reaction. In addition, the inflammatory process, present in allergic airway disease, was monitored with the use of the nasal lavage fluid examination. In accordance with Pignatti et al., a cut-off value of $4 \%$ and/or $1 \times 104$ eosinophils/ml for a significant postchallenge eosinophil increase has been identified [11]. In our patient, clinical symptoms appeared and the criteria concerning the eosinophils increase were fulfilled as well. In conclusion, in such cases specific inhalative challenge test is a "gold standard" in the diagnosis of occupational allergy. SICT was intended to demonstrate a direct relationship between exposure to Limonium sinuatum and an asthmatic response and it is particularly helpful in cases when standardized tests are unavailable.

\section{REFERENCES}

1. Jong NW, Vermeulen AM, Wijk RG, Groot H. Occupational allergy caused by flowers. Allergy 1998;53:204-9.

2. Ueda A, Tochigi T, Ueda T, Aoyama K, Manda F. Immediate type of allergy in statis growers. J Allergy Clin Immunol 1992;90:742-8.

3. Quirce S, García-Figueroa B, Olaguíbel JM, Muro MD, Tabar AI. Occupational asthma and contact urticaria from dried flowers of Limonium tataricum. Allergy 1993;48(4):285-90.

4. Becklake MR, Malo JL, Chan-Yeung M. Epidemiological approaches in occupational asthma. In: Bernstein IL, ChanYeung M, Malo JL, Bernstein DI, editors. Asthma in the workplace. New York: Marcel Dekker; 1999. p. 27-65.

5. Vandenplas O, Ghezzo H, Munoz X, Moscato G, Perfetti L, Lemière $\mathrm{C}$, et al. What are the questionnaire items most useful in identifying subjects with occupational asthma? Eur Respir J 2005;26:1056-63.

6. Tarlo SM, Balmes J, Balkissoon R, Beach J, Beckett W, Bernstein D, et al. Diagnosis and management of workrelated asthma: American College of Chest Physicians Consensus Statement. Chest 2008;134(3):1-41. Erratum in: Chest 2008;134(4):892. 
7. Kanerva L, Makinen-Kiljunen S, Kiistala R, Granlund H. Occupational allergy caused by spathe flower (Spathiphyllum wallisii). Allergy 1995;50:174-8.

8. Jansen AP, Visser FJ, Nierop G, de Jong NW, Waandersde Lijster de Raadt J, Vermeulen A, van Toorenenbergen AW. Occupational asthma to amarylis. Allergy 1996;51(11):847-9.

9. Vidal C, Polo F. Occupational allergy caused by Dianthus caryophillus, Gypsophila paniculata, and Lilium longiflorum. Allergy 1998;53:995-8.
10. Grob M, Wuthrich B. Occupational allergy to the umbrella tree (Schefflera). Allergy 1998:53:1008-9.

11. Pignatti P, Pala G, Pisati M, Perfetti L, Banchieri G, Moscato G. Nasal blown secretion evaluation in specific occupational nasal challenges. Int Arch Occup Environ Health 2010;83:217-23.

This work is available in Open Access model and licensed under a Creative Commons Attribution-NonCommercial 3.0 Poland License - http://creativecommons.org/ licenses/by-nc/3.0/pl/deed.en. 